\title{
48 HOW STAKEHOLDER ANALYSIS CAN BE MOBILIZED WITH ACTOR- NETWORK THEORY TO IDENTIFY ACTORS
}

\author{
A. Pouloudi \\ Athens University of Economics and Business \\ R. Gandecha \\ C. Atkinson \\ A. Papazafeiropoulou \\ Brunel University
}

\begin{abstract}
Actor-network theory studies provide detailed accounts of how human and nonhuman actors gradually form stable actor networks. However, due to their focus on a particular context, there is little generic guidance on how such relevant actors can be identified when a different research context is under study. The principles of(human) stakeholder behavior presented in this paper guide the identification of human stakeholders through an iterative, interpretive, dynamic and context-contingent process. We show how they can be adopted and extended to include the identification of nonhuman actants as well. Thus, we argue that they can be instrumental in providing a generic, context-free guidance to stakeholder identification that is currently missing from ANT studies.
\end{abstract}

Keywords: Stakeholder analysis, actor-network theory (ANT), actors, stakeholders, implementation

\section{ACTORS AND STAKEHOLDERS}

Actor-network theory (ANT) has its origins within the work of Callon $(1986,1991)$ and Latour (1987, 1992). According to ANT, humans and machines interact in a multiplicity of roles, together constituting networks that act as independent autonomous actors, the actor networks. An information system with its information technologies and 
its human users may be viewed as an actor network. In actor networks, actors collectively act; actor networks are by nature heterogeneous and information-based. Networks within ANT are also perceived as actors (Latour 1999; Suchman 2002). A key proposition of ANT is to treat human and nonhuman actors as well as networks symmetrically. However, there is little guidance on how these actors are identified. According to ANT, the researcher can trace the actor network by following the actors and observing what they do. The ANT literature provides several examples of how this can be applied in a specific context. However, the idea of following the actors cannot easily be translated to practical guidance for the researcher engaging with complex socio-technical phenomena. Stakeholder analysis is an approach much more explicit in this respect (Pouloudi 1999). However, the application of stakeholder analysis (unlike ANT) in the IS context has been predominantly restricted to the study of human stakeholders.

We argue that mobilizing stakeholder analysis with ANT, within research and practice, offers a means of identifying ANT actors systematically, thus enhancing ANT analysis. Although the notions of stakeholders (in stakeholder analysis) and actors (in ANT) are implicitly related, there is little research that attempts to bring the respective approaches together. This paper makes a contribution in this area by extending the stakeholder identification process to nonhuman actors and networks, with a view to support ANT analysis.

\section{STAKEHOLDER IDENTIFICATION IN ANT}

In order to offer generic guidance for stakeholder identification within ANT, we need a broad definition of stakeholders. Thus, we adapt Freeman's (1984) definition of organizational stakeholders for information systems: "A stakeholder of an information system is any individual, group, organization or institution who can affect or be affected by the information system under study."

Previous research in IS proposes a number of principles of stakeholder behavior that can be used to guide an interpretive identification and analysis of stakeholders (Table1). This approach puts forward a case for dynamic and iterative stakeholder identification. Such a dynamic and iterative process relates closely to some of the fundamental premises of actor-network theory, which "concentrates attention on a movement" (Latour 1999 p. 17).

The term nonhuman stakeholders has been used in information systems research already (e.g., Pouloudi and Whitley 2000; Vidgen and McMaster 1996). Here, we explore whether the stakeholder identification process cited above can include them. For this, we refer to the principles of stakeholder behavior and their implications as depicted in Table 1.

- The first principle emphasizes the importance of context and the specific time frame. It applies to human stakeholders as it does to nonhumans and networks. Indeed, ANT also emphasizes the importance of local context, as the stories told in ANT terms are largely defined by this.

- The second principle, prompting the researcher to explore links among stakeholders, is central to the notion of the actor network in ANT. Clearly, in ANT, 
Table 1. Propositions for Stakeholder Identification and Analysis (Pouloudi 1999)

\begin{tabular}{|l|l|}
\hline \multicolumn{1}{|c|}{ Principles of Stakeholder Behavior } & \multicolumn{1}{c|}{$\begin{array}{c}\text { Implications for Stakeholder } \\
\text { Identification and Analysis }\end{array}$} \\
\hline $\begin{array}{l}\text { 1. The set and number of stakeholders } \\
\text { are context and time dependent }\end{array}$ & $\begin{array}{l}\text { - stakeholder map should reflect the context } \\
\text { stakeholder map should be reviewed over } \\
\text { time }\end{array}$ \\
\hline $\begin{array}{l}\text { 2. Stakeholders cannot be viewed in } \\
\text { isolation }\end{array}$ & - consider how stakeholders are linked \\
\hline $\begin{array}{l}\text { 3. A stakeholder's role may change } \\
\text { over time }\end{array}$ & - adopt a long-term perspective \\
\hline $\begin{array}{l}\text { 4. Stakeholders may have multiple } \\
\text { roles }\end{array}$ & - study how perceptions change \\
\hline $\begin{array}{l}\text { 5. Different stakeholders may have } \\
\text { different perspectives and wishes }\end{array}$ & - there are different versions of the \\
stakeholder map to be drawn
\end{tabular}

these links or interactions occur among nonhuman and human entities. Bringing the two principles together, Latour (1999, p. 18) notes that "the network pole of actornetwork...refers to...the summing up of interactions through various kids of devices, inscriptions, forms and formulae, into a very local, very practical, very tiny locus."

- The third and fourth principles can also be interpreted broadly to include nonhuman stakeholders. For example, technological artifacts, such as information systems, can be put to different uses at different points in time or depending on the human agents that interact with them.

The implications of these principles for identifying human and nonhuman stakeholders in an actor network, as well as the networks themselves, is that stakeholders should reflect the dynamics of the local context and not be treated as static elements but, rather, revisited over time for new entries. Pouloudi (1998) suggests that each stakeholder can lead to the identification of further stakeholders; for example, stakeholders refer implicitly or explicitly to other stakeholders when interviewed. While a nonhuman stakeholder cannot be interviewed, other (multiple) actors may speak on its behalf. An IT director, an upgrade specification, or a user speaking on behalf of the technology are examples. Some nonhuman stakeholders (e.g., texts) include reference to other human or nonhuman stakeholders, therefore providing cues for further stakeholder identification.

The last three principles $(5,6$, and 7$)$ of Table 1 may be seen to concern human stakeholders exclusively, as they refer to perspectives, viewpoints, interests, and wishes. However, organizational networks, through successive translations, are made up of humans and nonhumans with aligned interests. These principles imply there can be 
different versions of who the stakeholders are, depending on the time frame and the perspective adopted. ANT does not explicitly support this process, even though it strives to allow new actors "to define the world in their own terms, using their own dimensions and touchstones" (Latour 1999, p 20).

The final principle draws particular attention to the political nature of stakeholder identification. While ANT acknowledges the importance of politics (Latour [1987] eloquently presents the politics of research), it does not do so explicitly in the process of describing the actor network. Instead, the ANT researcher is typically perceived as a reliable spokesperson for the network's establishment and/or the translation(s) of the actor network. It could be seen, though, that the researcher is acting on behalf of another (university or professional) network, one that is seeking to translate the network under investigation in line with its own (research) interests; indeed mobilizing stakeholder analysis is itself an analytical artifact, a machination, to achieve this.

\section{CONCLUSIONS AND FURTHER RESEARCH}

Atkinson and Brooks (2003) argue that despite ANT's call for a symmetric treatment of humans and nonhumans, the human/machine network duality "exists at the heart of the IS practice and research.” Aiming to support ANT's more holistic approach, this paper has made the case for using stakeholder analysis together with ANT. The actor network binds the stakeholders together; what influences one stakeholder can ripple through the network. This idea of strongly interlinked stakeholders, that are contingent on the context, has been put forward for studying stakeholders in information systems research (Pouloudi 1998). Taking these research proposals on board, and exploring their application to nonhuman stakeholders, we have argued that stakeholder analysis can provide guidance for the systematic identification of the multiple, interdependent human and nonhuman actors and networks. In turn, the powerful notion of translations in ANT, coupled with stakeholder analysis, can contribute to a richer understanding of complex phenomena. Our point is that both stakeholder and actor network analyses have been influenced by the element of alternative interpretations of the network under study.

Starting with a set of guidelines for stakeholder identification suggested in earlier information systems research, the paper explored their applicability alongside ANT studies. We have argued that, while the value of ANT is to a great extent due to its attention to the local context, and the recommendation to follow the actors in it, it does not help the researcher recognize who the actors worth following are. The approach suggested in this paper recognizes and addresses this fundamental methodological weakness, without overlooking the importance of the local context that is key to ANT. Specifically, it guides the researcher to consider who would be the relevant stakeholders for each further actor or actor network identified. It argues, in line with ANT, that actors should reflect the local context and are interlinked, but are also likely to change over time. Importantly, it makes explicit the political nature of ANT itself: the actors and actor networks identified are contingent on the researcher; thus there are different actor networks to be identified, different explanations to be given for their formation, and different stories to be told. This argument provides an opportunity to revisit ANT within an interpretive research framework. 
Thus, stakeholder analysis enhances ANT methodologically because it acknowledges explicitly the multiple stakeholder agendas, interests, and values. This prompts the researcher to recognize that there are multiple versions (or stories) of translation in each actor network, depending on the perspective adopted and the values and interests that characterize (or are inscribed in, in the case of nonhumans) stakeholder views. Research is, it may be argued, itself a translational struggle between the researchers and their university network and the subject network(s) under review.

Further research is called to explore the value of the guidelines presented in this paper in practice. We intend to look at one of the recent initiatives introduced by the National Heath Service (NHS) in the UK, the Integrated Care Record Service (ICRS). It is a "broad, continuously expanding and maturing portfolio of services covering the generation, movement and access to health records," which includes electronic prescribing in hospitals and workflow capacities to manage patient care pathways through the NHS (NHS 2002). The scale and ambitious outcomes of the ICRS project make it an interesting, complex context of information systems implementation for study. The interplay and critical role of both human stakeholders, such as patients and healthcare professionals, and nonhuman actors, such as care records, in the implementation of the ICRS have already prompted the use of ANT for its analysis (Gandecha et al. 2003). We believe that the line of research suggested in this paper can further help in the study of complex information systems implementations, such as the ICRS.

\section{REFERENCES}

Atkinson, C., and Brooks, L. "StructurANTion: A Theoretical Framework for Integrating Human and IS Research and Development," in J. Ross and D. Galletta, Proceedings of the Ninth Americas Conference on Information Systems, Tampa, 2003, pp. 2895-2902.

Callon M. "Some Elements of a Sociological Translation: Domestication of the Scallops and Fishermen of St Brieuc Bay," in J. Law (Ed), Power Action and Belief: A New Sociology of Knowledge,London: Routledge and Kegan Paul, 1986, pp. 196-233.

Callon M. "Techno-Economic Networks and Irreversibility," in J. Law (Ed.), A Sociology of Monsters? Essays on Power, Technology andDomination, London: Routledge, 1991, pp. 132-161.

Freeman, R. E. Strategic Management: A Stakeholder Approach, Cambridge, MA: Ballinger Publishing Co., 1984.

Gandecha, R.; Atkinson, C.; and Papazafeiropoulou, N. "Machinations and Machinations: The Integrated Care Records Service in the UK NHS," in J. Ross and D. Galletta (Eds.), Proceedings of the Ninth Americas Conference on Information Systems, Tampa, 2003, pp. 875-880.

Latour, B. "On Recalling ANT," in J. Law and J. Hassard (Eds.), Actor Network Theory and After, Oxford: Blackwell Publishers, 1999, pp. 15-25.

Latour, B Science in Action: How to Follow Scientists and Engineers Through Society, Cambridge, MA: Harvard University Press, 1987.

Latour, B. "Where Are the Missing Masses? Sociology of a Few Mundane Artefacts," in W. Bijker and J. Law (Eds.), Shaping Technology, Building Society: Studies in Sociotechnical Change, Cambridge, MA: MIT Press, 1992.

NHS. "The NHS Explained," National Health Service, 2002 (available online at http:// www.nhs.uk/thenhsexplained/how_the_nhs_works.asp). 
Pouloudi, A. "Aspects of the Stakeholder Concept and Their Implications for Information Systems Development," in R. H. Sprague (Ed.), Proceedings of the $32^{\text {nd }}$ Hawaii International Conference on Systems Sciences, Los Alamitos, CA: IEEE Computer Society Press, 1999.

Pouloudi, A. Stakeholder Analysis for Interorganisational Information Systems in Healthcare, Unpublished PhD Thesis, London School of Economics and Political Science, 1998.

Pouloudi, A., and Whitley, E. A. "Representing Human and Nonhuman Stakeholders: On Speaking with Authority," in R. Baskerville, J. Stage, and J. I. DeGross (Eds.), Organizational and Social Perspectives on Information Technology, Boston: Kluwer Academic Publishers, 2000, pp. 339-354.

Suchman, L. A. "Human/Machine Reconsidered,” Unpublished paper, Department of Sociology, Lancaster University, 2000 (available online at http://www.comp.lancs.ac.uk/sociology/ soc0401s.html).

Vidgen, R., and McMaster, T. "Black Boxes, Nonhuman Stakeholders and the Translation of IT Through Mediation," in W. J. Orlikowski, G. Walsham, M. R. Jones, and J. I. DeGross (Eds.), Information Technology and Changes in Organizational Work, London: Chapman \&Hall, 1996, pp. 250-271.

\section{ABOUT THE AUTHORS}

Athanasia (Nancy) Pouloudi is an assistant professor in the Department of Management Science and Technology at the Athens University of Economics and Business (AUEB), Greece. She holds a first degree in Informatics (AUEB, Greece), and an M.Sc. and Ph.D. degree in Information Systems (London School of Economics, UK). Her research focuses on strategic and social issues in information systems, specializing in electronic commerce, knowledge management and stakeholder issues with more than 70 publications in these areas. She is an associate editor for the European Journal of Information Systems, member of the Editorial Board of the Journal of Electronic Commerce in Organizations and the International Journal of Society, Information, Communication and Ethics, and has served as a Program Committee member for several international conferences. She has taught information systems at Brunel University (as a lecturer) and the London School of Economics (as a teaching assistant) and held visiting positions at Erasmus University (The Netherlands), the University of Hawaii (USA), and the Athens Laboratory of Business Administration (Greece). She has acted as scientific coordinator for AUEB on a number European projects. She is codirector of the Seventh ETHICOMP Conference and track chair for ework and virtual organizations for the European Conference on Information Systems 2004. Nancy can be reached at pouloudi@ aueb.gr or through herhome page, http://istlab.dmst.aueb.gr/ pouloudi/.

Reshma Gandecha is a researcher at the Centre of Healthcare Informatics and Computing at Brunel University. Originally a pharmacist, she undertook a BPharm and MrPharmS at UWCC at Cardiff School of Pharmacy in Wales. She has since worked in multiple environments as a practitioner in industry, hospital, and community settings. Through her work experience she has been interested in developing her management and information skills. Reshma further undertook MBA specializing in Information Management at Brunel University. She then pursued a career in medicines information especially managing the new entry of drugs at Health Policy Strategy level. Her current field of study is centred around multi-professional teams, including clinicians, managers, and information systems practitioners in affecting integrated organizational development especially in the UK IT/IS healthcare arena. Her current passion is Healthcare Information Systems Management in the UK National Health Service. Her research investigates the process of the National Programme for IT from strategy through to realization particularly the effective delivery of the integrated NHS Care records for real time patient care. She can be contacted via email at Reshma.Gandecha@brunel.ac.uk. 
Chris Atkinson is a senior lecturer in Information Systems in the UMIST Department of Computation. Until recently he was with Brunel University's Department of Information Systems and Computing Science. Originally a civil engineer, he undertook an M.Sc. and Ph.D. at Lancaster University in soft systems with a particular focus on systemic metaphor and its role in organizational problem solving. He has worked as both an academic and practitioner, focusing on how to integrate information systems development and organizational change, especially within healthcare settings. To that end, he has evolved and extensively deployed the Soft Information Systems and Technologies Methodology (SISTeM). Actor-network theory has recently emerged as an important framework for research, practice and methodological development. Its integration with structuration theory has proved fruitful as a further area for research and development. His field of study and practice has centred on working with multi-professional teams, clinicians, managers and information systems practitioners in affecting integrated organizational development. Chris may be contacted via christopher.atkinson@brunel.ac.uk.

Anastasia Papazafeiropoulou is a lecturer at the Information Systems and Computing department at Brunel University, where she received her Ph.D. She has worked as a technical trainee in the European Union (EU) in Brussels and as a research associate with expertise in electronic commerce at the Athens University of Economics and Business and Brunel University. She holds a first degree in Informatics (1994, Athens University of Economics and Business) and a M.Sc. in Information Systems (1997, Athens University of Economics and Business). Abastasia's research interests fall within social aspects and policy issues of electronic commerce, more specifically focusing on awareness creation and knowledge diffusion mechanisms available for electronic commerce adoption from Small and Medium Size enterprises. 